
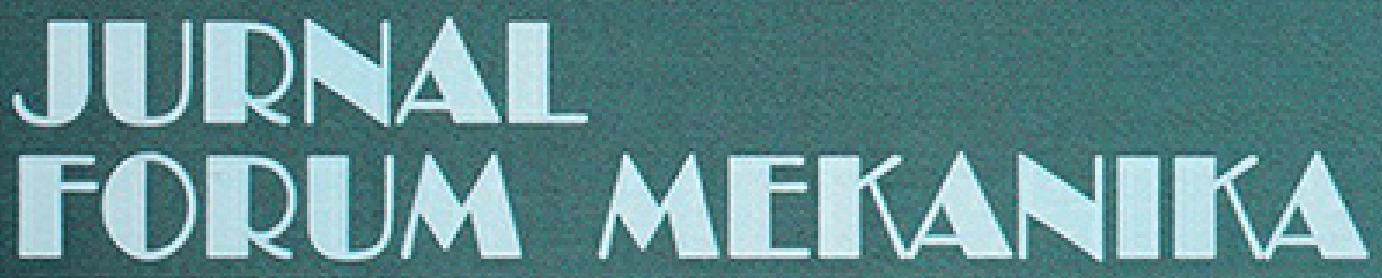

Volume 6 - Nomor 2 November 2017 ISSN : 2356-1491

ANALISIS RUMAH KABEL BAWAH TANAH PADA PROYEK PEKERJAAN JARINGAN UTILITAS SKTT 150 KV PLUMPANG - GAMBIR DYAH PRATIWI KUSUMASTUTI; IRMA SEPRIYANNA

STUDI KOMPARASI ANTARA PRACETAK MASIF DAN FLY SLAB STUDI KASUS: STRUKTUR GEDUNG RUSUNAWA SURAKARTA BUDI WICAKSONO

SISTEM DRAINASE ALIRAN BAWAH TANAH UNTUK DAERAH RAWAN LONGSOR (STUDI KASUS SUB DAS SUNGAI CIKAPUNDUNG, BANDUNG) ENDAH LESTARI

ANALISA STATISTIK DEBIT BANIIR DAN DEBIT ANDALAN SUNGAI KOMERING SUMATERA SELATAN DEVITA MAYASARI

STUDI EKSPERIMENTAL KUAT LENTUR BAJA PROFIL I KOMPAK SIMETRIS GANDA BERDASARKAN RSNI 03-1729-201X

DICKI DIAN PURNAMA; AKHMAD AMINULLAH; MUSLIKH

PENGGUNAAN PASIR LAUT TERHADAP KUAT TEKAN BETON KOTA BENGKULU TOMMYIDUWIN

ANALISA PENGARUH ADMIXTURE TERHADAP ABU TERBANG (FLY ASH) DAN BOTTOM ASH

TRI YUHANAH; NOVIA ADE MANDASARI

ANALISA KINERJA PERSIMPANGAN BERSINYAL PADA PERSIMPANGAN ANGKATAN 66 DAN RUAS JALAN R. SOEKAMTO KOTA PALEMBANG YULES PRAMONA ZULKARNAIN; IRMA INDRIANI 


\title{
STUDI EKSPERIMENTAL KUAT LENTUR BAJA PROFIL I KOMPAK SIMETRIS GANDA BERDASARKAN RSNI 03-1729-201X
}

\author{
DICKI DIAN PURNAMA \\ Jurusan Teknik Sipil, Sekolah Tinggi Teknik PLN Jakarta \\ Email : $\underline{\text { dicki@sttpln.ac.id }}$
}

AKHMAD AMINULLAH

Jurusan Teknik Sipil, Universitas Gadjah Mada Yogyakarta

Email : akhmadaminullah@ugm.ac.id

MUSLIKH

Jurusan Teknik Sipil, Universitas Gadjah Mada Yogyakarta

Email : muslikh7@yahoo.com

\begin{abstract}
Abstrak
Bahaya tekuk dan ketidakstabilan struktur mudah terjadi pada struktur balok baja, yang mengakibatkan stuktur akan mengalami kegagalan sebelum mencapai nilai kapasitas penampang ultimitnya sehingga kekuatan dari suatu balok tidak hanya ditentukan dari kapasitas ultimit penampangnya saja. Ketidakstabilan struktur dapat menyebabkan terjadinya tekuk torsi lateral meskipun tidak ada beban torsi yang bekerja pada balok. Usaha yang dapat dilakukan untuk mendukung stabilitas balok yaitu dengan cara memasang penahan lateral pada bagian sisinya. Penelitian ini dimaksudkan untuk mendapatkan informasi mengenai kuat lentur baja dengan cara membandingkan antara hasil teoritis berdasarkan SNI 03-1729-2002 dan (Rancangan Standar Nasional Indonesia) RSNI 03-1729.1-201x dengan hasil pengujian eksperimental dan hasil analisis elemen hingga (dengan bantuan program ABAQUS). Benda uji lentur yang diteliti termasuk kategori bentang panjang dengan panjang bentang uji 3,3 meter. Pembebanan dilakukan dengan sistem threepoint load. Hasil yang didapat dari pengujian menunjukan informasi bahwa kapasitas lentur penampang untuk benda uji bentang panjang hasil pengujian eksperimental memiliki perbedaan terkecil sebesar 33,18\% dari hasil teoritis. Adapun untuk cara analisis dengan FEM memiliki perbedaan sebesar 33,18\% dengan hasil eksperimen. Kegagalan yang terjadi untuk benda uji bentang panjang yaitu akibat tekuk torsi lateral.
\end{abstract}

Kata kunci : Ketidakstabilan struktur, tekuk torsi lateral, kuat lentur

\begin{abstract}
The danger of buckling and instability structures easily occurs on the steel beam structure, it will make the structure fails before it reaches the cross section ultimate capacity. In that case the strength of a beam is not only determined by cross-section ultimate capacity. The instability of the structure causes lateral torsional buckling eventhough there is no torque on the beam. There is one way to support the stability of the beam; by installing lateral support on its side. This research is intended to obtain information about flexural strength by comparing the theoretical results based on SNI 03-1729-2002 and (Indonesian National Standard Draft) RSNI 03-1729.1$201 x$ with the results of experimental testing and finite element analysis results (using the ABAQUS program). The flexural specimens which are studied are in the long-span with a length of 3.3 meters span test. The loading uses three-point load system. The results of the test show information that flexural strength for the long-span specimen from experimental test results has the smallest difference of $33.18 \%$ of the theoretical result. As for analysis with FEM also hasthe same difference of $33.18 \%$ with the experimental results. Failure that occurs for long-span specimen is due to lateral torsional buckling failures.
\end{abstract}

Keywords : instability structure, lateral torsional buckling, flexural strength.

\section{Latar Belakang}

Pada struktur baja, elemen-elemen tersebut memiliki bentuk/profil yang berbeda dibanding struktur dengan elemen beton. Karena material baja memiliki kekuatan yang lebih tinggi dibanding material beton maka profil pada struktur baja umumnya lebih ramping. Hal ini dilakukan agar terjadi efektifitas penampang, bentuk elemen baja yang terlalu besar malah akan menyebabkan berat dari elemen tersebut akan semakin besar dan akan 
mengakibatkan biaya yang dibutuhkan akan semakin besar pula. Bentuk penampang yang relatif tipis tersebut seringkali menyebabkan ketidakstabilan struktur sehingga elemen akan mengalami kegagalan sebelum mencapai nilai kapasitas penampang ultimitnya. Salah satu perilaku struktur baja yang dapat menyebabkan hal tersebut yakni perilaku tekuk (buckling). Khusus untuk elemen balok fenomena tekuk dibagi menjadi tekuk lokal, dan tekuk torsi lateral.

Wacana pembaruan peraturan baja terbaru RSNI 03-1729-201x masih dalam tahap pembahasan. Namun seperti yang diketahui bersama bahwa RSNI 03-1729-201x masih mengadopsi peraturan AISC 360-05 ${ }^{1}$. Sedangkan kondisi di Indonesia berbeda dalam hal mutu baja hasil pabrikasi dengan kondisi USA (Nawir, 2005) ${ }^{2}$. Sehingga kiranya perlu dilakukan penelitian untuk memberikan informasi mengenai RSNI 03-1729-201x apakah telah memenuhi kriteria yang dipersyaratkan.

Penelitian ini dilakukan untuk mengetahui nilai kuat lentur dan faktor modifikasi $\mathrm{C}_{\mathrm{b}}$ pada balok tanpa pengaku lateral dan dengan pengaku lateral sesuai perhitungan kuat lentur RSNI baja 03-1729201x dan SNI baja 03-1729-2002 dan membandingkannya dengan kuat lentur baja hasil ekperimen, mencari tahu apakah tipe keruntuhan yang terjadi sesuai dengan persyaratan yang diberikan dan mengetahui manakah metode yang lebih mendekati dan aman antara RSNI 03-1729.1201X dan SNI 03-1729-2002 dengan hasil eksperimen.

Pada penelitian ini profil yang digunakan yaitu profil I kompak simetris ganda terhadap sumbu kuat, baja profil I menggunakan produk dari PT Krakatau Wajatama dibawah naungan PT Krakatau Steel dengan mutu baja BJ 41 yakni mutu baja yang dipersyaratkan memiliki kuat leleh $250 \mathrm{MPa}$ dan kuat putus $410 \mathrm{MPa}$, penelitian lebih difokuskan pada nilai tekuk torsi lateral pada baja profil I kompak simetris ganda dan analisis FEM hanya dilakukan pada benda uji bentang panjang (BL-1).

\section{Landasan Teori}

Tidak semua keruntuhan yang terjadi pada struktur balok diakibatkan kekuatan penampang yang tidak cukup untuk menahan beban yang bekerja, kadangkala keruntuhan balok terlebih dahulu disebabkan oleh ketidakstabilan struktur balok itu sendiri yang mengakibatkan terjadinya tekuk torsi lateral, meskipun tidak ada beban torsi yang bekerja pada balok tersebut.

\section{Kondisi Batas Momen Lentur}

Kegagalan suatu komponen struktur lentur (balok) dapat terjadi ketika balok mencapai momen plastis tetapi kegagalan komponen struktur lentur dapat juga ditentukan oleh 2 macam kriteria. Kriteria pertama yaitu profil akan mengalami lateral torsional buckling (tekuk torsi lateral) yang diakibatkan adanya displacement dan rotasi di tengah bentang, namun hal ini tidak mengalami perubahan bentuk. Kriteria kedua yaitu profil akan mengalami local buckling (tekuk lokal) pada sayap tekan dan juga pada pelat badan, sehingga mengakibatkan berubahnya bentuk profil, hal ini diakibatkan oleh adanya rasio kelangsingan yang relatif sangat besar antara tinggi pelat badan terhadap tebalnya.

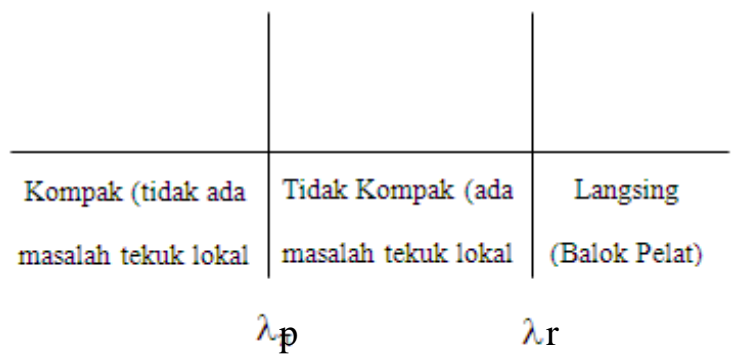

Gambar 1. Pengelompokan Batang (Segui, 2007)

Tabel 1. Batas-Batas $\lambda_{\mathrm{p}}$ dan $\lambda_{\mathrm{r}}$ Profil WF

\begin{tabular}{|l|c|c|c|}
\hline Elemen & $\lambda$ & $\lambda_{\mathrm{p}}$ & $\lambda_{\mathrm{r}}$ \\
\hline Flens & $\frac{b_{f}}{2 t_{f}}$ & $0,38 \sqrt{\frac{E}{f_{y}}}$ & $1,0 \sqrt{\frac{E}{f_{y}}}$ \\
\hline Web & $\frac{h}{t_{w}}$ & $3,76 \sqrt{\frac{E}{f_{y}}}$ & $5,70 \sqrt{\frac{E}{f_{y}}}$ \\
\hline
\end{tabular}

Sumber : Segui, 2007

\section{Kuat Nominal Lentur Penampang}

Kekuatan lentur nominal, Mn harus nilai terendah yang diperoleh sesuai dengan keadaan batas dari leleh (momen plastis) dan tekuk torsi lateral :

Akibat Leleh

$M_{n}=M_{p}=F_{y} Z_{x}$

\section{Akibat Tekuk Torsi Lateral}

a. Bila $\mathrm{L}_{\mathrm{b}}<\mathrm{L}_{\mathrm{p}}$

Untuk SNI 03-1729-2002 ${ }^{4}$ nilai momen lentur pada bentang pendek sama dengan RSNI 031729.1-201x.

$\mathrm{M}_{\mathrm{n}}=\mathrm{M}_{\mathrm{p}}$

$M_{p}=f_{y} Z$ atau $1,5 M_{y}$

$M_{y}=f_{y} S$

b. Bila $\mathrm{L}_{\mathrm{p}}<\mathrm{L}_{\mathrm{b}}<\mathrm{L}_{\mathrm{r}}$

Nilai momen lentur pada RSNI 03-1729.1-201x ${ }^{5}$ yaitu :

$M_{n}=C_{b}\left[M_{p}\left(M_{p}-0,7 F_{y} S_{x}\right) \frac{L_{b}-L_{p}}{L_{r}-L_{p}}\right]<M$

Untuk SNI 03-1729-2002 nilai momen lentur pada bentang menengah yaitu :

$$
M_{n}=C_{b}\left[M_{r}\left(M_{p}-M_{r}\right) \frac{L_{r}-L_{p}}{L_{r}-L_{p}}\right]<M_{p}
$$




\section{c. Bila $\mathrm{L}_{\mathrm{b}}>\mathrm{L}_{\mathrm{r}}$}

Nilai momen lentur untuk bentang panjang pada RSNI 03-1729.1-201x yaitu:

$\mathrm{Mn}=\mathrm{F}_{\mathrm{cr}} \mathrm{S}_{\mathrm{x}} \leq \mathrm{M}_{\mathrm{p}}$

$$
F_{c r}=c_{b} \frac{\pi^{2} E}{\left(\frac{L_{b}}{r_{t s}}\right)^{2}} \sqrt{1+0,078 \frac{J c}{S_{x} h_{0}}\left(\frac{L_{b}}{r_{t s}}\right)^{2}}
$$

Untuk SNI 03-1729-2002 nilai momen lentur pada bentang panjang yaitu :

$$
\begin{aligned}
& \mathrm{M}_{\mathrm{n}}=\mathrm{M}_{\mathrm{r}} \leq \mathrm{M}_{\mathrm{p}} \\
& M_{n}=C_{b} \frac{\pi}{L} \sqrt{E I_{y} G J+\left(\frac{\pi E}{L}\right)^{2} I_{y} I_{w}}
\end{aligned}
$$

Nilai $\mathrm{L}_{\mathrm{p}}$ pada SNI 03-1729-2002 dan RSNI 031729.1-201x memiliki batasan yang sama, yakni:

$L_{p}=1,76 r_{y} \sqrt{\frac{E}{F_{y}}}$

Batasan nilai $\mathrm{L}_{\mathrm{r}}$ yang diberikan pada RSNI 031729.1-201x yakni:

$L_{r}$

$=1,95 r_{t s} \frac{E}{0,7 F_{y}} \sqrt{\frac{J c}{S_{x} h_{0}}+\sqrt{\left(\frac{J c}{S_{x} h_{0}}\right)^{2}+6,76\left(\frac{0,7 F_{y}}{E}\right)^{2}}}$

Sedang batasan nilai $\mathrm{L}_{\mathrm{r}}$ yang ada pada SNI 03-17292002 yakni:

$L_{r}=r_{y}\left[\frac{X_{1}}{f_{L}}\right] \sqrt{1+\sqrt{1+X_{2} f_{L}^{2}}}$

Faktor modifikasi untuk momen tak seragam

$$
C_{b} \min =\left(\frac{12,5 M_{\max }}{2,5 M_{\max }+3 M_{A}+4 M_{B}+3 M_{C}}\right)
$$

Dimana :

$\mathrm{M}_{\max }=$ momen maks di segmen $\mathrm{L}_{\mathrm{b}}$

$\mathrm{M}_{\mathrm{A}}=$ momen di $1 / 4 \mathrm{~L}_{\mathrm{b}}$

$\mathrm{M}_{\mathrm{B}}=$ momen di $1 / 2 \mathrm{~L}_{\mathrm{b}}$

$\mathrm{M}_{\mathrm{C}}=$ momen di $3 / 4 \mathrm{~L}_{\mathrm{b}}$

\section{Stabilitas}

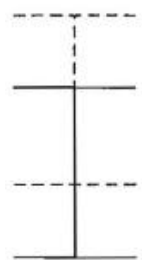

(a)

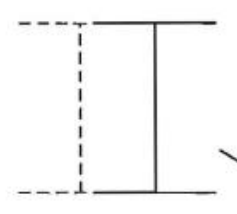

(b)

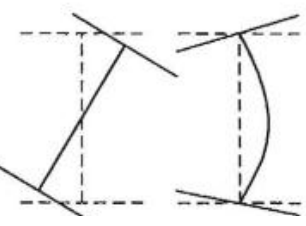

(c) (d)
Gambar 2. Deformasi Balok (Sumber : Segui, 2007)

\section{Tekuk Torsi Lateral}

Ada dua macam kategori sokongan lateral, yakni :
1. Sokongan lateral menerus yang diperoleh dengan menanamkan flens tekan balok ke dalam pelat lantai.

2. Sokongan lateral pada jarak tertentu yang diberikan oleh balok atau rangka melintang dengan kekakuan yang cukup.

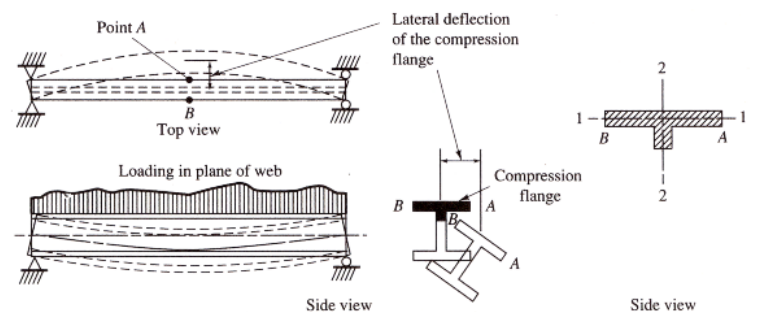

\begin{tabular}{|c|c|}
\hline \multicolumn{2}{|c|}{ Faktor yang Mempengaruhi Tekuk Torsi Lateral } \\
\hline Material & $\begin{array}{l}\text { Modulus Geser }(\mathrm{G}) \\
\text { Modulus Young's (E) }\end{array}$ \\
\hline $\begin{array}{l}\text { Penampang } \\
\text { Melintang }\end{array}$ & $\begin{array}{c}\text { Konstanta Torsi (It) } \\
\text { Konstanta Tekuk (Iw) } \\
\text { Momen Inersia Sumbu Lemah (Iz) }\end{array}$ \\
\hline Geometris & Panjang Balok (L) \\
\hline $\begin{array}{l}\text { Kondisi } \\
\text { Batas }\end{array}$ & $\begin{array}{c}\text { Lentur Terhadap Sumbu Utama } \\
\text { Lentur Terhadap Sumbu Minor } \\
\text { Tekuk }\end{array}$ \\
\hline Beban & $\begin{array}{c}\text { Tipe Pembebanan (terdistribusi, terpusat, } \\
\text { dll) } \\
\text { Letak Beban (sayap atas, pusat geser, } \\
\text { sayap bawah, dll) }\end{array}$ \\
\hline
\end{tabular}

Gambar 3. Balok Terkekang Lateral pada UjungUjungnya (Setiawan, 2008)

Tabel 2. Faktor yang Mempengaruhi Tekuk Torsi Lateral

\section{Metodologi Penelitian}

\section{Bahan Penelitian}

Benda uji yang digunakan pada pengujian ini adalah baja profil IWF dengan dimensi $150 \times 75 \times 5 \times 7$ dari produk PT Krakatau Wajatama dibawah naungan PT Krakatau Steel dengan mutu BJ41 yang dibuat 1 sample untuk benda uji tipe 1 .

\section{Peralatan Penelitian}

Peralatan yang digunakan dalam penelitian ini adalah :

1. Loading Frame

2. Hydraulic Jack

3. Load Cell

4. LVDT (Linear Variable Differential

Transformer)

5. Data Logger

6. Strain gauge

7. Strain indicator dan Switching Box 


\section{Pemodelan Benda Uji}

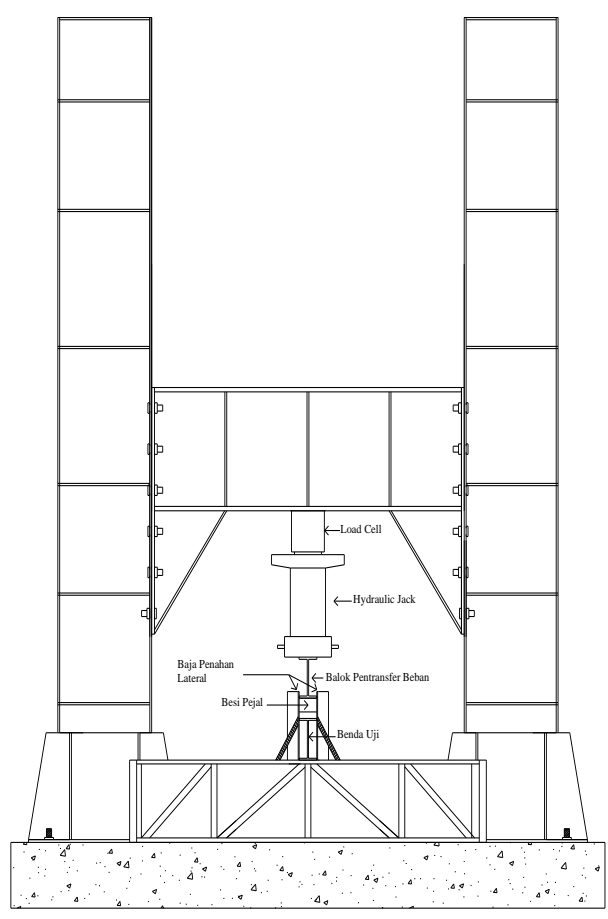

Gambar 4. Tampak depan Setting Up Pengujian

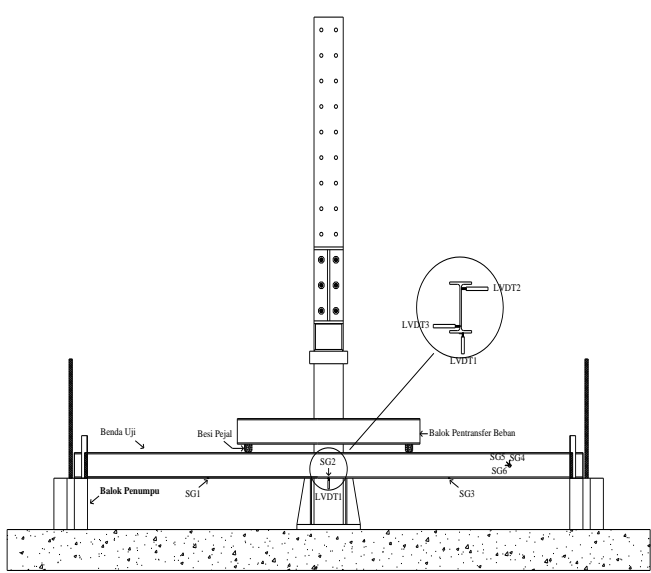

Gambar 5. Tampak Samping Pengujian

\section{ANALISIS DAN PEMBAHASAN}

\section{Kuat Lentur Eksperimen Benda Uji}

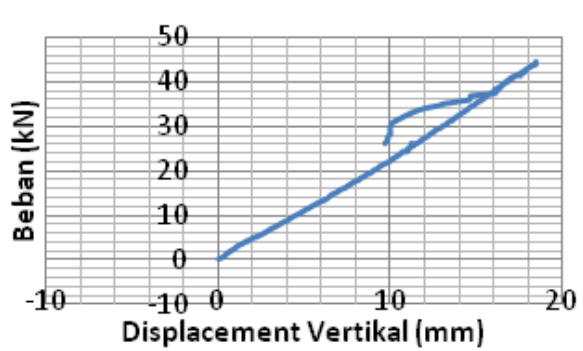

Gambar 6. Kurva Beban-Displacement Vertikal Benda Uji
Dari pengujian tarik didapatkan kuat tarik baja $f_{\mathrm{y}}$ sebesar $393 \mathrm{MPa}$ dan kuat ultimit $f_{\mathrm{u}}$ sebesar $529 \mathrm{MPa}$

Pada Gambar 6 tampak bahwa benda uji BL-1 masih dalam kondisi elastis dimana kurva yang terjadi masih linier. Hingga pada beban 4,47 ton. Dari kurva diatas dapat diketahui jenis kegagalan yang terjadi pada benda uji tipe 1 (BL-1). Dimana benda uji BL-1 mengalami kegagalan akibat tekuk torsi lateral.

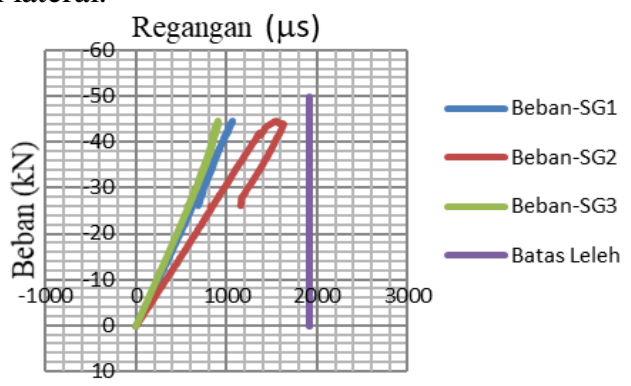

Gambar 7. Beban-Regangan BL-1

Pada Gambar 7 tergambar kurva beban-regangan untuk strain gauge yang berada di sayap bawah pada jarak $1 / 4$ bentang, $1 / 2$ bentang dan $3 / 4$ bentang. Dari ketiga strain gauge tersebut, semuanya menunjukan bahwa pada bagian $1 / 4,1 / 2$, dan $3 / 4$ bentang belum mengalami leleh. Sehingga bisa diambil kesimpulan bahwa kegagalan yang terjadi karena tekuk torsi lateral.

Displacement arah horizontal ditinjau pada sisi kiri dan kanan benda uji. Hal ini dilakukan agar didapatkan informasi tentang rotasi yang dialami oleh penampang. Dari data pengamatan, benda uji mengalami rotasi sebesar $15^{\circ}$.

Pada Gambar 8 tampak bahwa kemiringan/rotasi benda uji terus bertambah bersamaan dengan bertambahnya beban yang diberikan hingga mencapai beban puncaknya.

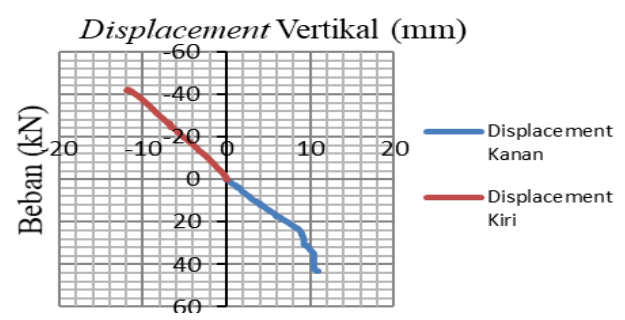

Gambar 8. Kurva Beban-Displacement Horisontal BL-1

Hasil perhitungan kapasitas momen lentur untuk benda uji tipe 1 disajikan dalam Tabel 3 .

Tabel 3 menunjukan kapasitas balok secara teoritis dan eksperimental. Dapat dilihat bahwa kemampuan balok hasil eksperimental memiliki nilai yang lebih besar dari perhitungan teoritis yakni sebesar 34,85 dan 33,18 \%. Hal ini menunjukan bahwa kapasitas balok dari perhitungan teoritis lebih konservatif dari kondisi eksperimental baik untuk SNI 03-1729-2002 maupun RSNI 03-1729-201x. 
Tabel 3. Kapasitas Momen Lentur Benda Uji BL-1 Hasil Eksperimen

\begin{tabular}{|c|c|c|c|c|c|}
\hline $\begin{array}{c}\text { Type } \\
\text { Benda } \\
\text { Uji }\end{array}$ & $\begin{array}{c}\mathrm{M}_{\mathrm{n}} \text { SNI 03- } \\
\begin{array}{c}729-2002 \\
(\mathrm{kN} . \mathrm{m})\end{array}\end{array}$ & $\begin{array}{c}\mathrm{M}_{\mathrm{n}} \text { SNI 03- } \\
1729-201 \mathrm{X} \\
(\mathrm{kN} . \mathrm{m})\end{array}$ & $\begin{array}{c}\mathrm{M}_{\mathrm{n}} \\
\text { Eksperimental } \\
(\mathrm{kN} . \mathrm{m})\end{array}$ & $\begin{array}{c}\text { Perbedaan } \\
(2):(4) \\
(\%)\end{array}$ & $\begin{array}{c}\text { Perbedaan } \\
(3):(4) \\
(\%)\end{array}$ \\
\hline$(1)$ & $(2)$ & $(3)$ & $(4)$ & $(5)$ & $(6)$ \\
\hline 1 & 16,10 & 16,42 & 24,59 & 33,18 & 34,85 \\
\hline
\end{tabular}

\section{Kuat Lentur FEM Benda Uji}

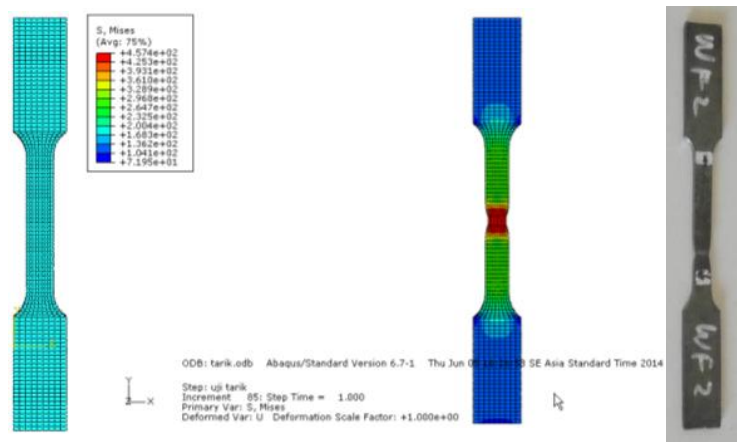

Gambar 9. Pemodelan Benda Uji Tarik ABAQUS Sumber : Hasil Analisis, 2014

Sebelum melanjutkan ke proses analisis, dilakukan terlebih dahulu verifikasi nilai material properties yang akan diinputkan dalam ABAQUS. Langkah verifikasi yang dilakukan yakni dengan memodelkan pengujian tarik kemudian membandingkan hasilnya dengan hasil pengujian tarik eksperimental.

Perbandingan Kuat Tarik Hasil Eksperimental dan FEM dapat dilihat pada Gambar 10.

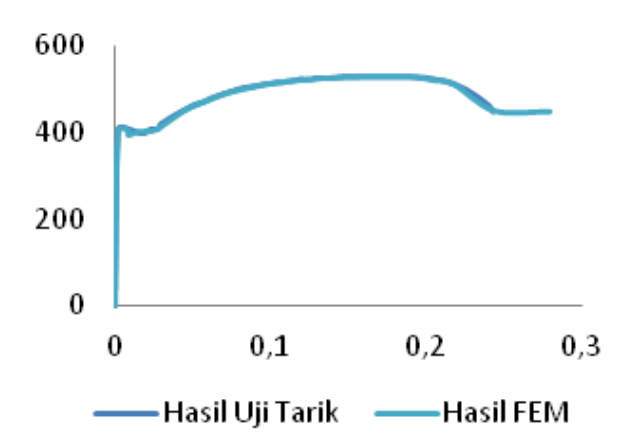

Gambar 10. Perbandingan Kuat Tarik Hasil Eksperimental dan FEM
Pada Gambar 11 tampak bahwa benda uji BL-1 hasil analisis FEM masih dalam kondisi elastis meskipun tidak elastis dimana kurva yang terjadi masih linier hingga pada beban ultimitnya sebesar 29,1 kN. Dari kurva diatas dapat diketahui jenis kegagalan yang terjadi pada pada benda uji. Dimana benda uji BL-1 mengalami kegagalan akibat tekuk torsi lateral.

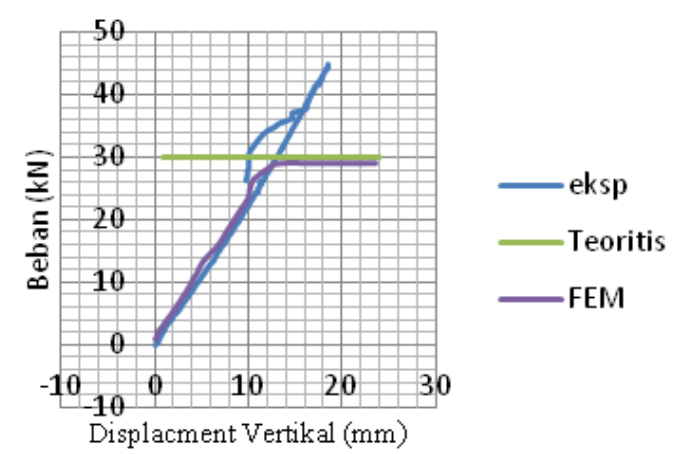

Gambar 11. Beban-Regangan BL-1 FEM

Tabel 4 menunjukan kapasitas balok secara teoritis dan FEM. Dapat dilihat bahwa kemampuan balok hasil analisis FEM memiliki perbedaan dari perhitungan teoritis yakni sebesar 33,18\%.

Tabel 4. Kapasitas Momen Lentur Benda Uji BL-1 Hasil FEM

\begin{tabular}{|c|c|c|c|c|c|c|c|}
\hline $\begin{array}{c}\text { Type } \\
\text { Benda } \\
\text { Uji }\end{array}$ & $\begin{array}{c}\mathrm{M}_{\mathrm{n}} \text { SNI 03- } \\
\begin{array}{c}1729-2002 \\
(\mathrm{kN} . \mathrm{m})\end{array}\end{array}$ & $\begin{array}{c}\mathrm{M}_{\mathrm{n}} \text { SNI 03- } \\
1729-201 \mathrm{X} \\
(\mathrm{kN} . \mathrm{m})\end{array}$ & $\begin{array}{c}\mathrm{M}_{\mathrm{n}} \text { FEM } \\
(\mathrm{kN} . \mathrm{m})\end{array}$ & $\begin{array}{c}\text { Mn Eksp } \\
(\mathrm{kN} . \mathrm{m})\end{array}$ & $\begin{array}{c}\text { Perbedaan } \\
(2):(5) \\
(\%)\end{array}$ & $\begin{array}{c}\text { Perbedaan } \\
(3):(5) \\
(\%)\end{array}$ & $\begin{array}{c}\text { Perbedaan } \\
(4):(5) \\
(\%)\end{array}$ \\
\hline$(1)$ & $(2)$ & $(3)$ & $(4)$ & $(5)$ & $(6)$ & $(7)$ & $(8)$ \\
\hline 1 & 16,01 & 16,42 & 16,01 & 24,59 & 33,18 & 34,85 & 33,18 \\
\hline
\end{tabular}

\section{Pola Keruntuhan Benda Uji}

Pada Gambar 4 dapat diketahui jenis kegagalan yang terjadi pada benda uji tipe 1. Pada benda uji BL-1, dapat diketahui perilaku bahwa beban yang bekerja tampak linier terhadap displacement vertikal yang terjadi. Namun setelah beban dihilangkan, benda uji BL-1 akan kembali ke bentuk semula. Hal ini berarti bahwa benda uji BL-1 belum mengalami kelelehan dan kegagalan yang terjadi diakibatkan oleh tekuk torsi lateral. 

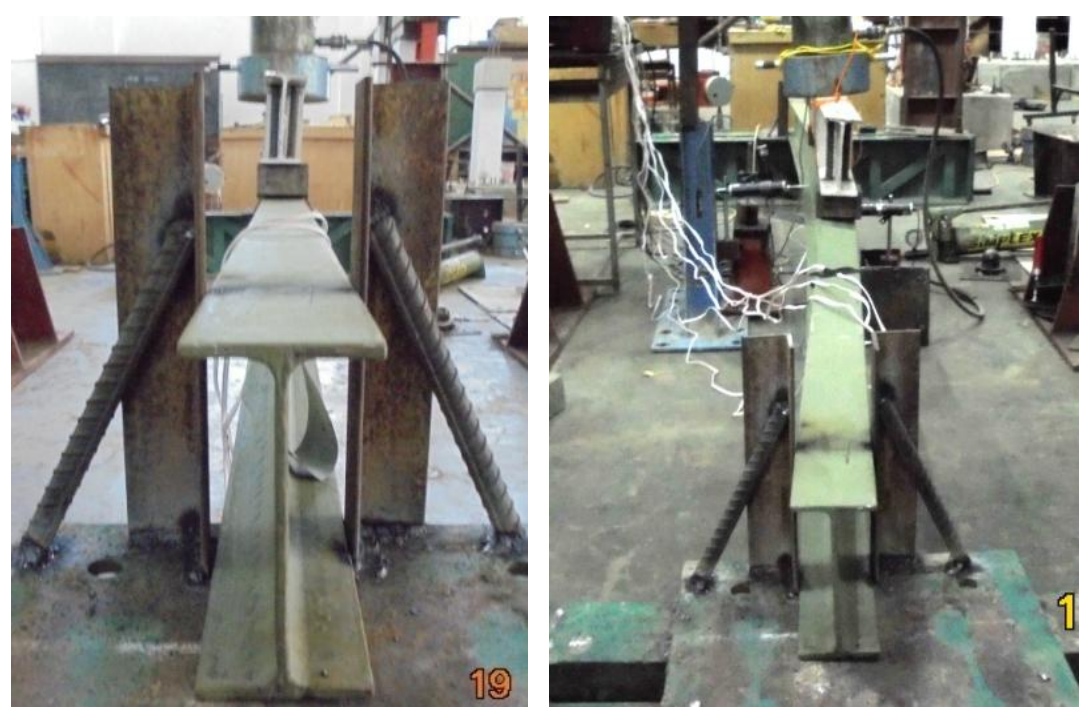

Gambar 12. Benda Uji BL-1 Sebelum (kiri) dan Setelah Pengujian (kanan)

Kegagalan akibat tekuk torsi lateral tercapai sebelum benda uji mengalami leleh. Hal ini terjadi karena masalah stabilitas pada balok bentang panjang akan lebih menentukan dibandingkan dengan kapasitas penampangnya. Pada Gambar 13 tampak bahwa benda uji kembali ke bentuk semula setelah beban dihilangkan.
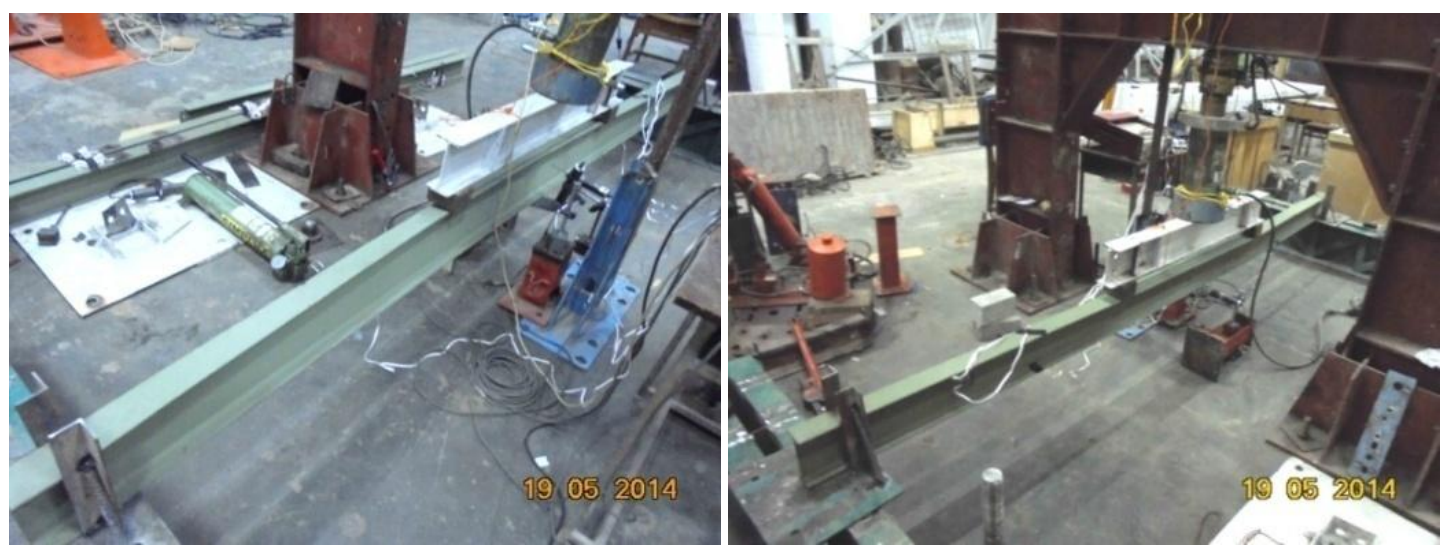

Gambar 13. Benda Uji BL-1 Sebelum (Kiri) dan Setelah Beban Dihilangkan (Kanan)
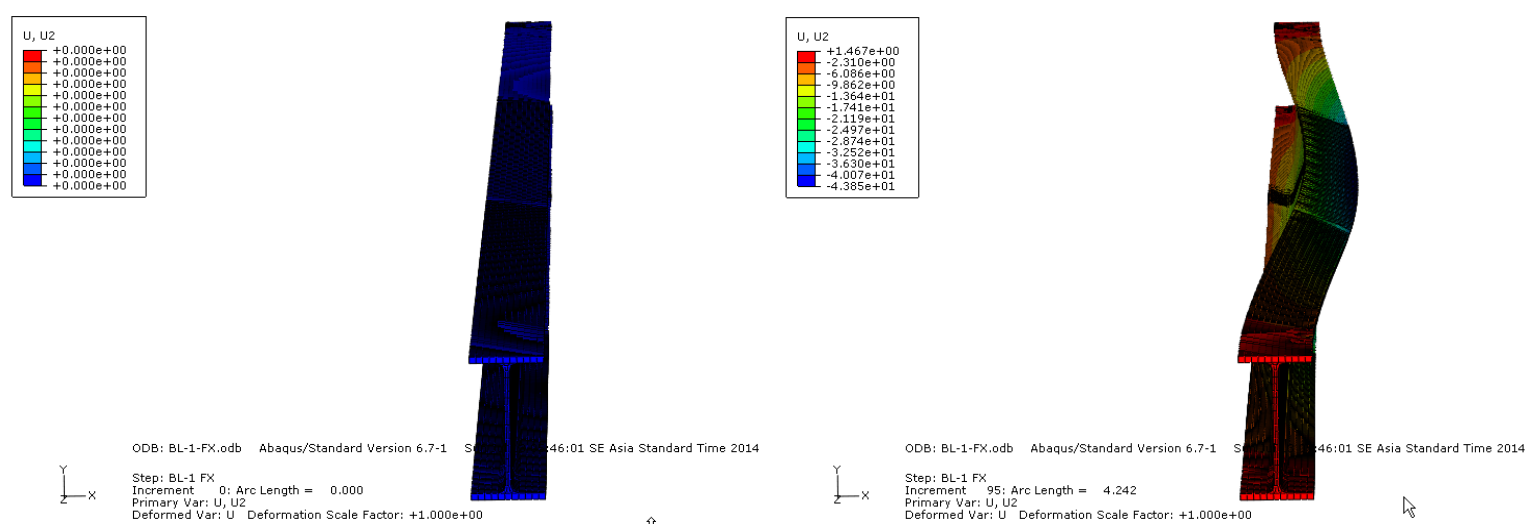

Gambar 14 Benda Uji FEM Tipe 1 Sebelum (kiri) dan Setelah Pembebanan (kanan) 


\section{Kesimpulan}

1. Kapasitas lentur penampang untuk benda uji bentang panjang hasil pengujian eksperimental memiliki perbedaan terkecil sebesar 33,18\% dari hasil teoritis. Sedangkan untuk cara FEM memiliki perbedaan sebesar $33,18 \%$ dengan hasil eksperimen.

2. Kegagalan yang terjadi untuk benda uji BL-1 yaitu akibat tekuk torsi lateral.

\section{DAFTAR PUSTAKA}

[1] Segui, William T. 2007. "Steel Design Fourth Edition". Thomson. The University of Memphis.AISC. 2005 "Load and Resistance Factor Design Spesification for Structural Steel Buildings". American Institute of Steel Construction. Chicago. Illinois.
[2] Rasidi, Nawir. 2005. "Studi Eksperimental Perbandingan Nilai Faktor Reduksi ( $\phi)$ Profil Baja Tabung Kotak di Indonesia”. PROC. ITB Sains \& Tek. Vol. 37 A, No. 2, 2005, 155-169.

[3] Badan Standarisasi Nasional. 2002. "Tata Cara Perencanaan Struktur Baja Untuk Bangunan Gedung". Departemen Pekerjaan Umum. Jakarta

[4] Badan Standarisasi Nasional. 201x. "Spesifikasi untuk Gedung Baja Struktural". (Badan Standarisasi Nasional) BSN. Jakarta.

[5] Setiawan, Agus. 2008. "Perencanaan Struktur Baja dengan Metode LRFD”. Erlangga. Jakarta. 